\title{
Correction to: Effects of behavioural activation on substance use and depression: a systematic review
}

\author{
Carmela Martínez-Vispo ${ }^{1 *}$, Úrsula Martínez ${ }^{2}$, Ana López-Durán ${ }^{1}$, Elena Fernández del Río ${ }^{3}$ and Elisardo Becoña ${ }^{1}$
}

\section{Correction to: Subst Abuse Treat Prev Policy (2018) 13:36 \\ https://doi.org/10.1186/s13011-018-0173-2}

Following publication of the original article [1], we have been notified that there are some parts in the article text that need to be changed as per below:

- Table 2 Ratings of methodological quality by EPHPP should change Blinding rating of Busch et al. (2017) [43] from Weak to Moderate and Global rating from Moderate to Strong;

- Abstract text part should be changed to: One trial received weak methodological quality, five moderate, and two strong;

- Results text part in Methodological quality assessment should be changed to: Overall, two studies received a methodological quality rating of strong [43, 49], five studies of moderate [45-48, 50], and one study of weak [44];

- Discussion text part should be changed to: Regarding the quality of the studies, it is of note that only two of the studies reached the qualification of strong methodological quality $[43,49]$.

\section{Author details}

${ }^{1}$ Smoking Cessation and Addictive Disorders Unit, Department of Clinical Psychology and Psychobiology, Faculty of Psychology, University of Santiago de Compostela, Santiago de Compostela, Spain. ${ }^{2} T o b a c c o$ Research and Intervention Program, Department of Health Outcomes and Behaviour, $\mathrm{H}$.
Lee Moffitt Cancer Center, Tampa, FL, USA. ${ }^{3}$ Department of Psychology and Sociology, University of Zaragoza, Zaragoza, Spain.

Published online: 31 May 2020

\section{Reference}

1. Martínez-Vispo C, et al. Effects of behavioural activation on substance use and depression: a systematic review. Subst Abuse Treat Prev Policy. 2018;13: 36. https://doi.org/10.1186/s13011-018-0173-2.

The original article can be found online at https://doi.org/10.1186/s13011018-0173-2.

* Correspondence: carmela.martinez@usc.es

${ }^{1}$ Smoking Cessation and Addictive Disorders Unit, Department of Clinical

Psychology and Psychobiology, Faculty of Psychology, University of Santiago

de Compostela, Santiago de Compostela, Spain

Full list of author information is available at the end of the article

C C The Author(s). 2020 Open Access This article is licensed under a Creative Commons Attribution 4.0 International License, which permits use, sharing, adaptation, distribution and reproduction in any medium or format, as long as you give appropriate credit to the original author(s) and the source, provide a link to the Creative Commons licence, and indicate if changes were made. The images or other third party material in this article are included in the article's Creative Commons licence, unless indicated otherwise in a credit line to the material. If material is not included in the article's Creative Commons licence and your intended use is not permitted by statutory regulation or exceeds the permitted use, you will need to obtain permission directly from the copyright holder. To view a copy of this licence, visit http://creativecommons.org/licenses/by/4.0/ The Creative Commons Public Domain Dedication waiver (http://creativecommons.org/publicdomain/zero/1.0/) applies to the data made available in this article, unless otherwise stated in a credit line to the data. 